\title{
Planktic and benthic foraminiferal distribution patterns as a response to changes in surface fertility and ocean circulation: a case study from the Late Albian 'Amadeus Segment' (Central Italy)
}

\author{
SIMONE GALEOTTI
}

Istituto di Geologia dell'Università, Facoltà di Scienze, Località Crocicchia, I-61029 Urbino, Italy.

\begin{abstract}
A combined geochemical and micropalaeontological study of the late Albian 'Amadeus Segment' of the Aptian-Albian organic-rich Scisti a Fucoidi Formation in central Italy shows that planktic foraminiferal assemblages record changes in abundance and composition which are markedly related to $\mathrm{CaCO}_{3}$ and Total Organic Carbon content of the sediments. The distribution pattern of different genera seems to record changes in nutrient supply and surface water temperature. Changes in palaeoceanographic regime are also reflected in abundance, composition and trophic structure of benthic foraminiferal assemblages as a response to variations of oxygen content and organic flux to the sea floor. $J$. Micropalaeontol. 17(1): 87-96, April 1998.
\end{abstract}

\section{INTRODUCTION}

Modern planktic foraminifera display a distribution which is essentially shaped by environmental factors such as temperature and nutrient distribution, and organized in major water masses. Their mid-Cretaceous representatives have been used for palaeoclimatic and palaeoceanographic reconstruction (Hart \& Bailey, 1979; Wonders, 1980; Caron \& Homewood, 1983; Leckie, 1987; Premoli Silva et al., 1989b; Premoli Silva \& Sliter, 1994) in a period when global climate is considered to have been considerably warmer than the present ice-house state.

The present study aims to delineate the planktic and benthic foraminiferal distribution patterns from the late Albian 'Amadeus Segment' (Coccioni \& Galeotti, 1993) of the Fiume Bosso section (Fig. 1) and to attempt a palaeoecological interpretation.

The Amadeus Segment, which belongs to the 'Whitish Marly Limestone Member' of the Scisti a Fucoidi Formation (Coccioni et al., 1987, 1989) (Fig. 2), is dated to the planktic foraminiferal Biticinella breggiensis zone and Ticinella praeticinensis subzone. It consists of a rhythmic alternation of marls, calcareous marls and black shales. Two radiolarian-rich layers also occur.

Rhythmic Cretaceous sequences (e.g. the Aptian-Albian Scisti a Fucoidi) of the Umbria-Marche basin of central Italy have been studied by several authors (de Boer, 1982; Schwarzacher \& Fischer, 1982; Fischer et al., 1985, 1991; de Boer \& Wonders, 1984; Herbert \& Fischer, 1986; among others). De Boer (1982) and Herbert \& Fischer (1986) suggested that the marl-limestone bedding couplets resulted from variations in carbonate supply and record a productivity cycle, in which the carbonate beds denote peaks and the shales lows in pelagic carbonate productivity. These authors determined that the marked lithologic alternation which characterizes Albian sediments of the Umbria-Marche basin is orbitally controlled. On the basis of

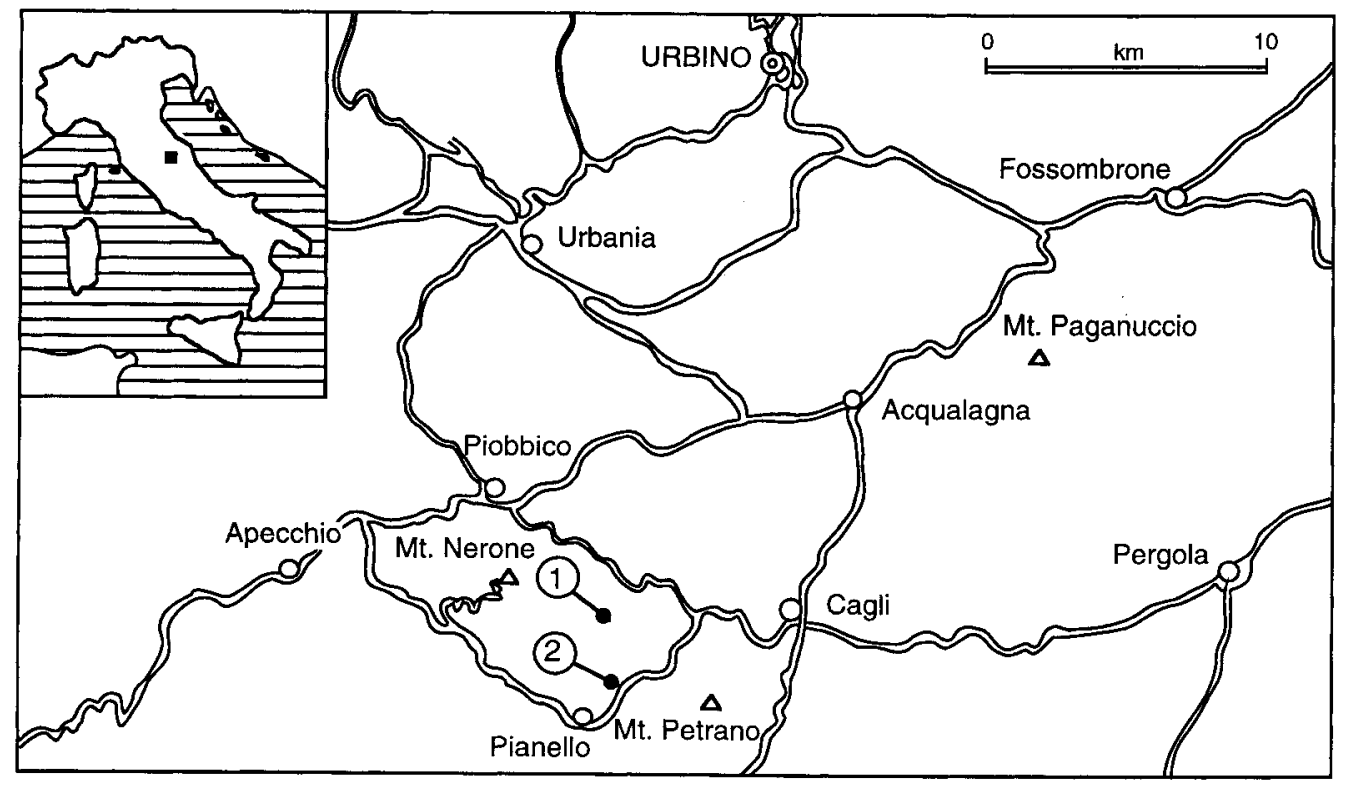

Fig. 1. Location of the Poggio le Guaine (1) and Fiume Bosso (2) sections which according to Coccioni et al. (1990a and $b$ ) are the reference sections for the Scisti a Fucoidi Formation in the Umbria-Marche Basin. The sections outcrop in the area of Geological Map of Italy, F. 290 'Cagli', $1: 50.000$. 


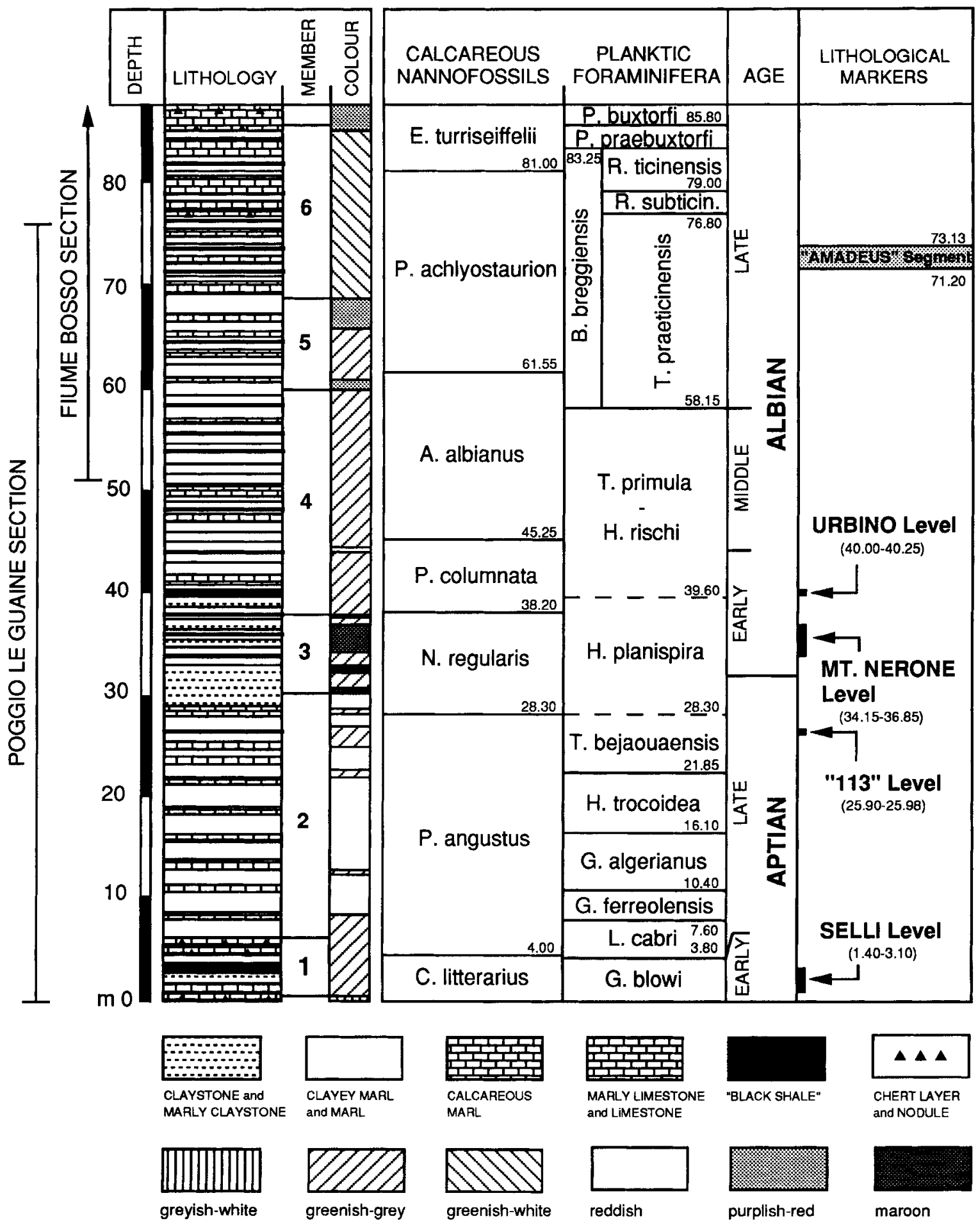

Fig. 2. Lithostratigraphy and biostratigraphy of the Poggio le Guaine-Fiume Bosso composite sequence (after Coccioni \& Galeotti, 1993). Numbers indicate metres above the base. In the right column are reported the position of the Amadeus Segment and the position of four distinctive global and regional marker black-shales layers. 


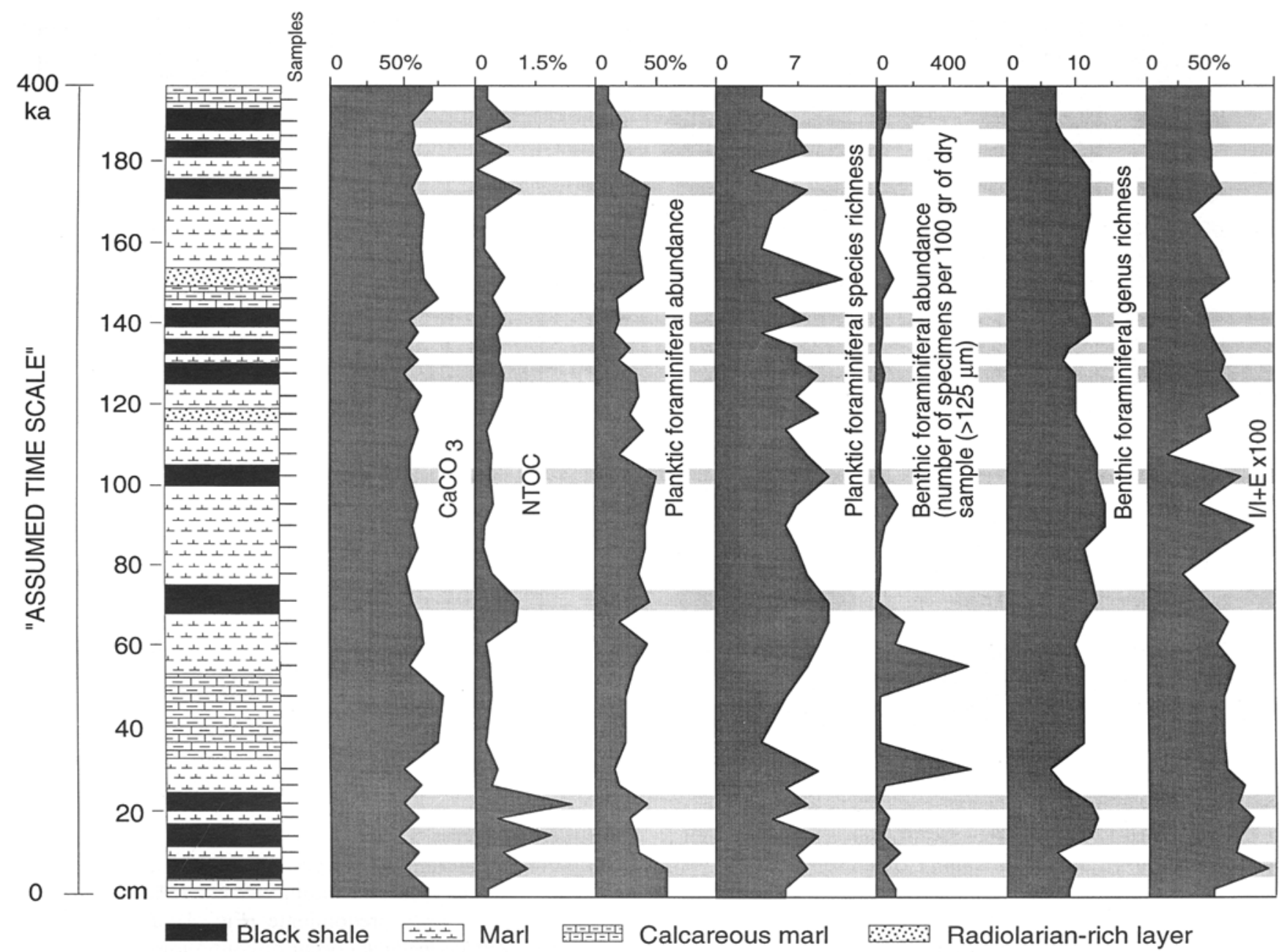

Fig. 3. Generalized lithological log of the Amadeus segment and variations of $\mathrm{CaCO}_{3}$ content and faunal parameters. Abbreviations as follows: $\mathrm{Ag}=$ Agglutinated benthic foraminifera, $\mathrm{CH}=$ Calcerous-hyaline benthic foraminifera, $\mathrm{I}=$ Infaunal forms, $\mathrm{E}=$ Epifaunal forms.

isotopic data from the Moria section, de Boer \& Wonders (1984) concluded that the carbonate highs of this portion of the Scisti a Fucoidi were deposited under cooler and more fertile waters. Changes in the abundance of planktic foraminifera and trace fossils distributions were interpreted as being orbitally controlled (Premoli Silva et al., 1989a,b; Erba \& Premoli Silva, 1994).

According to Coccioni \& Galeotti (1993) the abundance, taxonomic composition, morphology, and test size of benthic foraminifera fluctuate greatly from layer to layer throughout the Amadeus Segment, therefore indicating that the orbital forcing markedly influenced the distribution of certain species, genera and morphogroups.

Because it provides an opportunity to integrate available data obtained from different proxies, the Amadeus Segment is ideal for evaluating at $\mathrm{cm}$-scale the response of different genera and species of planktic foraminifera to cyclic fluctuations of the palaeoceanographic regimes.

\section{MATERIAL AND METHODS}

The Amadeus Segment was sampled bed by bed, and 38 samples were taken from a deep trench to eliminate surface contamina- tion. The $\mathrm{CaCO}_{3}$ content of each sample was estimated volumetrically with a Dietrich-Fruhling calcimeter. The Total Organic Carbon (TOC) content was estimated with a Netzsch Simultaneous Thermal Analyser STA 429 and then calculated on a basis free of $\mathrm{CaCO}_{3}$ content to obtain a normalized value (NTOC). A constant terrigenous input can be assumed for the studied interval (Fischer \& Herbert, 1986). Calculating the TOC value on a basis free of $\mathrm{CaCO}_{3}$ content, would, therefore, avoid disturbance due to changes in sedimentation rate, allowing a better evaluation of organic matter fluxes and preservation on the sea-floor.

Sample preparation for foraminiferal study involved the crushing of $150 \mathrm{~g}$ of sediment sample and disaggregation with diluted hydrogen peroxide solution, washing through a $63 \mu \mathrm{m}$ sieve and drying. The abundance of planktic foraminifera was estimated by counting identifiable organisms on a graduated screen and comparing obtained values with those from grainsize diagrams (Baccelle \& Bosellini, 1965). A random portion of the washed residue was picked, yielding at least 300 specimens of planktic foraminifera from the fraction greater than $63 \mu \mathrm{m}$. Planktic foraminiferal abundance and diversity (species rich- 


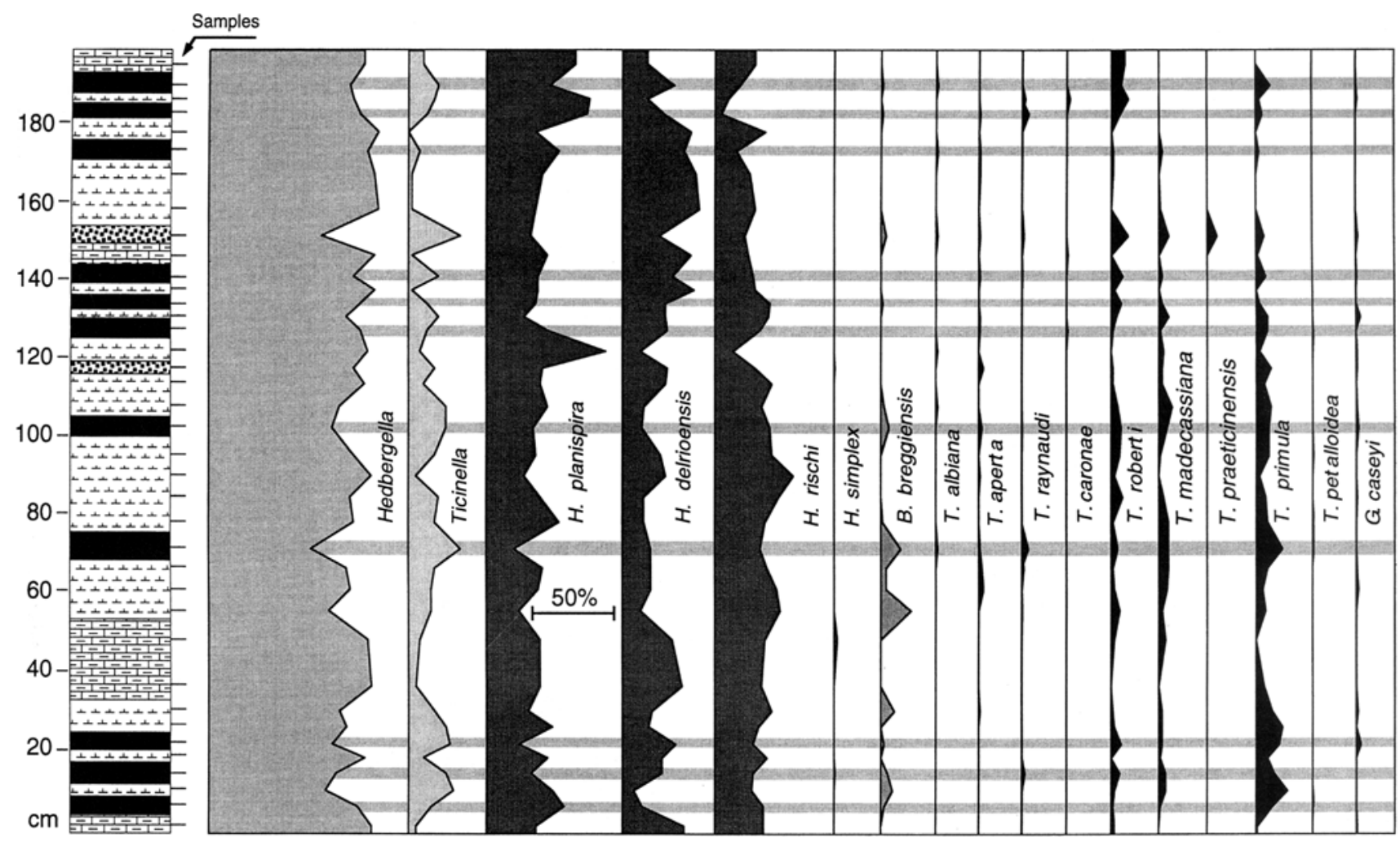

Fig. 4. Generalized lithological log of the Amadeus Segment and relative abundance percentages of planktic foraminiferal genera and species.

ness) were plotted against lithology, $\mathrm{CaCO}_{3}$ content, NTOC, and the benthic foraminiferal faunal parameter records from Coccioni \& Galeotti's (1993) data set (Fig. 3). The relative abundance of each genus and species was plotted against lithology (Fig. 4), Cross-correlation plots of planktic foraminiferal diversity and generic abundance, and $\mathrm{CaCO}_{3}$ content were also calculated (Fig. 5).

On the basis of their chamber arrangement and inferred mode of life the benthic foraminifera were allocated into ten morphogroups following different authors (Jones \& Charnock, 1985; Bernhard, 1986; Corliss \& Chen, 1988; Koutsoukos \& Hart, 1990).

The generic classification followed herein is mainly based on that outlined by Loeblich \& Tappan (1987). Classification at species level is based on a wide range of literature. A list of the species cited in the text and used in the figures is given in the Appendix.

\section{RESULTS}

The $\mathrm{CaCO}_{3}$ record of the Amadeus Segment ranges from 50 to $75 \%$ (Fig. 3), with minima of $50-55 \%$ in the black shales. The TOC content assumes values ranging from a minimum of $0.21 \%$ total weight (t.w.) in Sample 36 to a maximum of $3.1 \%$ t.w. in Sample 6; its average value is $0.4 \%$ t.w. in the carbonate highs to $1.5 \%$ t.w. in the black shales (Fig. 3).

Planktic and benthic foraminiferal assemblages record marked changes in abundance and in composition throughout the studied interval which are largely related to the $\mathrm{CaCO}_{3}$ content of the sediment also reflecting the NTOC content (Figs 3 and 4).

\section{Planktic foraminifera}

Planktic foraminiferal assemblages are composed of 16 species belonging to four genera, among which Hedbergella and, subordinately, Ticinella predominate (Fig. 4). Biticinella and particularly Globigerinelloides occur discontinuously throughout the studied interval. Preservation is moderate to good.

As already shown by Premoli Silva et al. $(1989 a, b)$ the abundance of planktic foraminifera peaks at intermediate values of $\mathrm{CaCO}_{3}$ content whereas it decreases in the carbonate highs assuming medium values in the black shale layers.

In addition, a peculiar distribution of planktic foraminiferal genera and species was recognized. When $\mathrm{CaCO}_{3}$ content reaches the highest values, planktic foraminiferal content is very low and Hedbergella represents almost the entire assemblage with a maximum relative percentage in abundance of $98 \%$. By contrast, the relative abundance of Ticinella and Biticinella breggiensis peaks at low values of $\mathrm{CaCO}_{3}$ content (Figs 4 and 5). The discontinuous distribution of Globigerinelloides caseyi does not enable a thorough evaluation. However, it must be noted that $G$. caseyi is absent when $\mathrm{CaCO}_{3}$ content reaches values higher than $65 \%$.

Fluctuations in relative abundance of different species of Hedbergella do not parallel the record of the genus to which they belong. Conversely, Ticinella madecassiana, T. primula, and $T$. roberti, which have a continuous distribution in contrast to other species of Ticinella, display variations in relative abundance that parallel the record of the genus, and covary with the $\mathrm{CaCO}_{3}$ content and NTOC. In fact they become more abundant in the marly portions of the Amadeus Segment where the black shale/marl couplets are clearly recognizable (i.e. the marly 


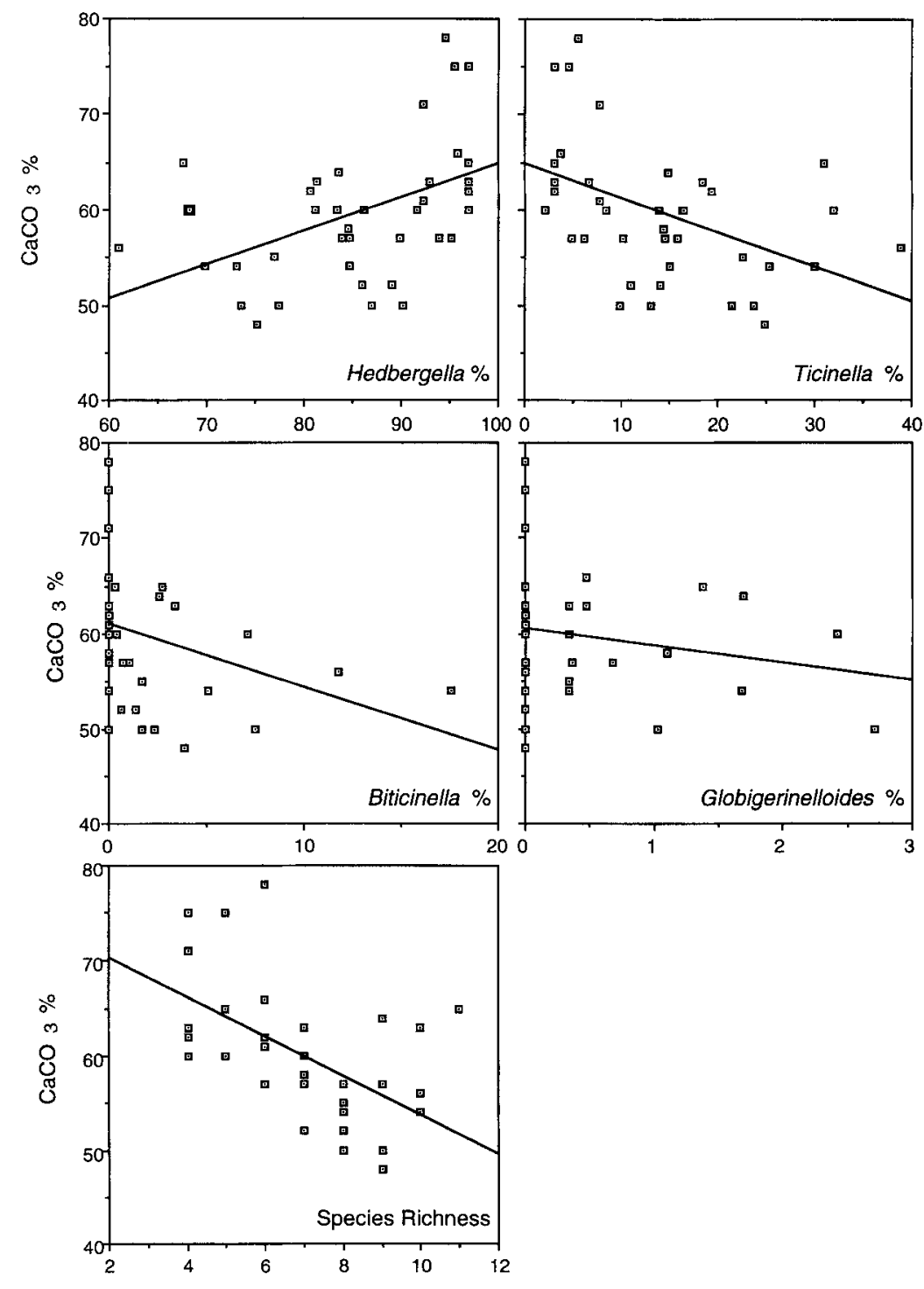

Fig. 5. Cross correlation scattergrams of planktic foraminiferal genera relative abundance and species richness, and $\mathrm{CaCO}_{3}$ content of the sediments. High $\mathrm{CaCO}_{3}$ content would be related, according to de Boer (1982) and Herbert \& Fischer (1986), to periods of maximal productivity.

portion of the bundles of Herbert \& Fischer, 1986).

The species richness also shows a correspondence with lithology reaching the highest values with low values of $\mathrm{CaCO}_{3}$ and high values of NTOC (Figs 4 and 5). Its maximum value has been recorded in a marly layer (Sample 30) which is, however, characterized by a rather low $\mathrm{CaCO}_{3}$ percentage and a NTOC content which is double the average from the carbonate highs.

\section{Benthic foraminifera}

Benthic foraminiferal assemblages are composed of calcareous hyaline and both calcareous and siliceous agglutinating forms. Preservation is moderate to good. Forty-two species were identified belonging to 22 genera among which Gyroidinoides,
Arenobulimina, Dorothia, and Clavulinoides predominate.

The benthic foraminiferal assemblages change with lithology (Fig. 6) and three distinct associations can be recognized (see Fig. 9 for details).

According to Coccioni \& Galeotti (1993) these changes in benthic foraminiferal assemblages abundance and composition are related to the response of benthic foraminiferal communities to fluctuations of nutrient flux and the oxygen content at the seabottom, as well as the sedimentation rate.

Moreover, the distribution of many species, genera and morphogroups appears to be cyclic (Figs 6 and 7). However, some of them (e.g. Marssonella oxycona, Pleurostomella, and branching morphotypes) exhibit a discontinuous distribution that it is very difficult to interpret. 


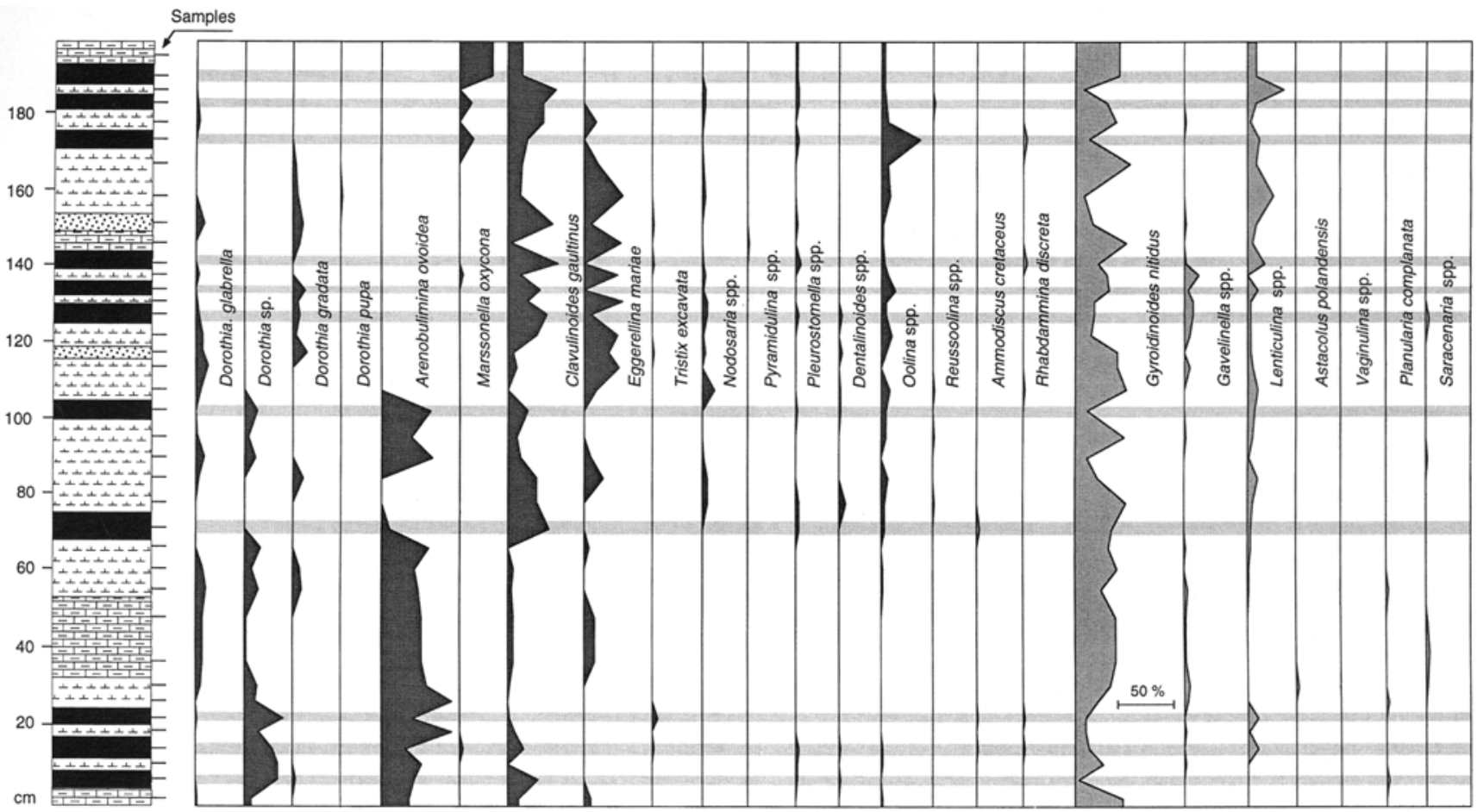

Fig. 6. Generalized lithological log of the Amadeus Segment and relative abundance percentages of benthic foraminiferal genera and species. Dark stippled = infaunal forms, light stippled epifaunal forms

\section{DISCUSSION}

Fischer \& Herbert (1986) studied an $8 \mathrm{~m}$ core segment from the Upper Albian portion of the Scisti a Fucoidi containing the Segment-1 of Premoli Silva et al. (1989) which in turn is lithoand bio-stratigraphically correlatable to the Amadeus Segment, suggesting that the lithologic alternation is related to Milankovitch cycles.

According to these authors, bedding couplets reflect the precession, bundles record the short eccentricity cycles, and dissolution effects did not play an important role in determining the alternation of marl-limestone beds. Moreover, the very good state of preservation of planktic foraminifera in the black shale layers suggests that the sequence was not notably affected by carbonate migration. This is one of the reasons why Herbert \& Fischer (1986) interpreted lithologic cycles from the late Albian Scisti a Fucoidi as chiefly due to cyclical changes in carbonate productivity and sea-floor stagnation. Variations in detrital supply, oscillations in carbonate dissolution, and episodic winnowing have, in fact, to be excluded as the cause of the lithological cycles (Fischer \& Herbert, 1986; Herbert \& Fischer, 1986). Moreover, Erba (1992) suggested a minor effect of diagenesis on nannofossil assemblages from the Amadeus Segment. The latter author also noticed that species diversity among nannofossil assemblages is higher during carbonate lows.

Any relation between the $\mathrm{CaCO}_{3}$ and NTOC content and planktic foraminiferal distribution pattern has, therefore, to be seen in terms of a response of these organisms to orbital perturbation capable of triggering changes in the upper water column structure and nutrient supply. In particular, the carbonate-rich layers, where the highest abundances of Hedber- gella occur, indicate periods of high fertility and a strong mixing of the surface waters. The shaly intervals, where Ticinella and Biticinella breggiensis display relative abundance peaks, would represent, according to Premoli Silva et al. $(1989 a, b)$, periods of lower productivity and greater water stratification. Accordingly, Hedbergella thrived under eutrophic conditions, whereas more oligotrophic conditions favoured Ticinella and Biticinella (Figs 8 and 9). Coccioni et al. (1992) suggested that Globigerinelloides preferred mesotrophic conditions, which seems to be likely as $G$. caseyi is absent when the $\mathrm{CaCO}_{3}$ content is higher than $65 \%$. According to Caron \& Homewood (1983) planktic foraminiferal forms such as Hedbergella living in the shallowest waters are favoured during periods of lower temperature and overall environmental instability, whereas Ticinella and Biticinella which are inferred to live at greater depths (Leckie, 1987) should thrive under conditions of environmental stability.

Changes in water temperature might have played a fundamental role in controlling the abundance and composition of depth-stratified planktic foraminiferal assemblages, as well as inducing changes in water structure, depth of the thermocline, water density and salinity. Leary et al. (1989) documented peak abundances of hedbergellids from the Cenomanian of southern England associated with higher temperature of surface waters as indicated by isotopic evidence. Bréhéret et al. (1985) reported important changes in the planktic foraminiferal assemblage composition related to both lithologic and geochemical variations across the organic-rich early Albian Paquier level in the Vocontian Basin where high abundances of small-sized hedbergellids occur. The latter authors suggested that deeper dweller ticinellids were affected by an expansion of the oxygen minimum 


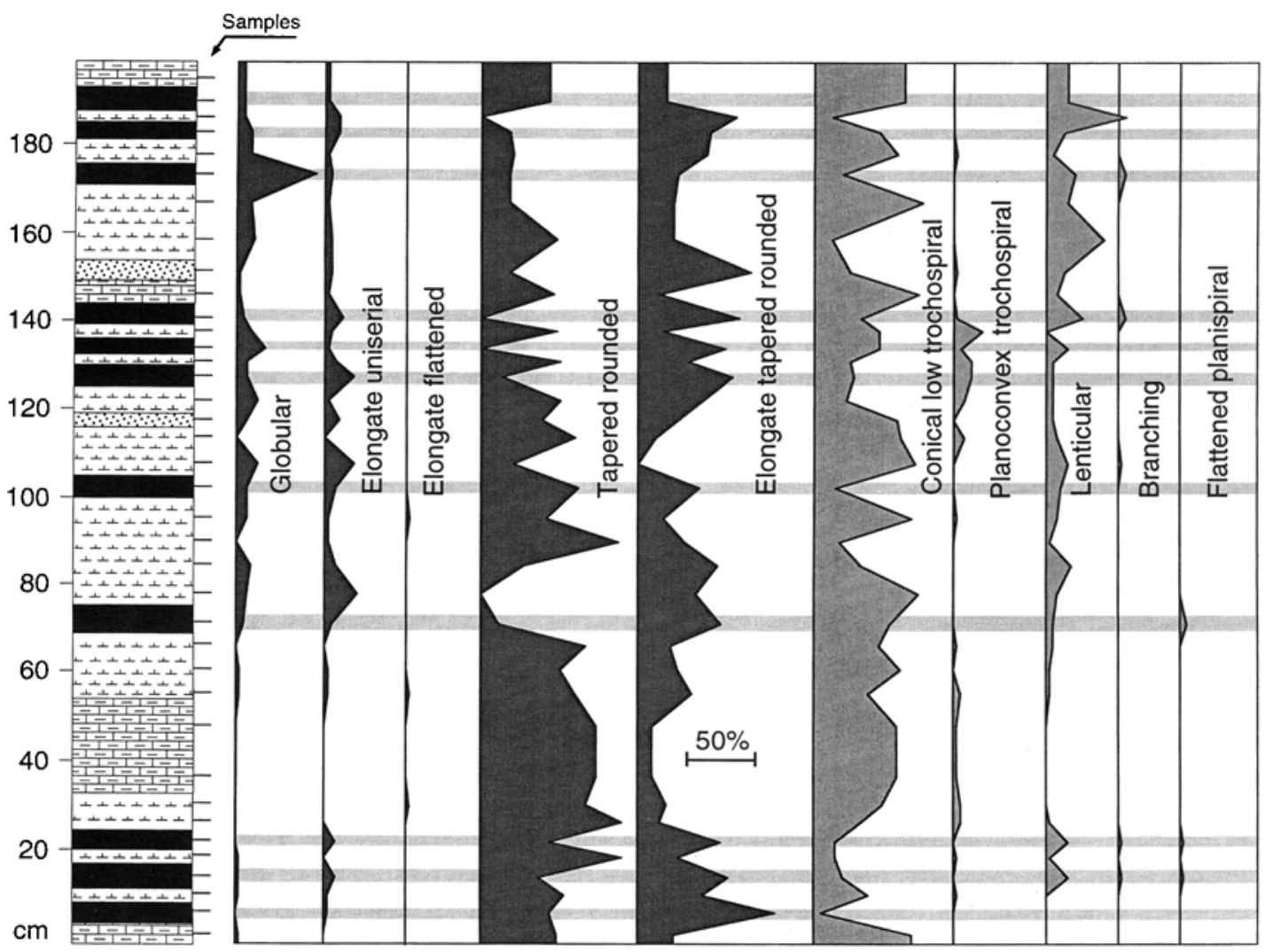

Fig. 7. Generalized lithological log of the Amadeus Segment and relative abundance percentages of benthic foraminiferal morphogroups. Dark stippled = infaunal forms, light stippled epifaunal forms.

zone during periods of higher surface fertility and organic-rich horizon deposition.

Conversely, the peak abundances of Hedbergella in the Amadeus Segment occur within the calcareous marly layers which, according to de Boer \& Wonders (1984), were deposited during periods of lower surface water temperatures. It seems then likely that rather than temperature nutrient availability was a limiting factor controlling the abundance of opportunistic taxa ( $r$-selected) such as Hedbergella. Temperature might have been, indeed, the most important factor in controlling the distribution of K-selected taxa such as Ticinella and Biticinella, which thrived during warmer periods when the thermocline should have been deeper, allowing the development of ecological niches available for deeper dwellers. Different species of Hedbergella seem instead to be less sensitive to variations of the thermocline position possibly because they occupied ecological niches very close to the sea-surface.

Interestingly, the conditions which favour the opportunistic rselected planktic foraminifera tend to make the benthic foraminiferal assemblages $\mathrm{K}$-selected as reported in Fig. 9. Conversely, during the deposition of the black shale layers when the K-selected ticinellids are favoured, benthic foraminiferal assemblages become r-selected and characterized by high dominance and predominance of small-sized specimens (Fig. 9). This trend comes as a surprise because in deep ocean settings the benthic fauna is entirely dependent on the flux of organic matter from the surface ocean for food.
It is usually difficult to interpret what chiefly contributes to the breaking of normal recycling of carbon into the ocean. Reduction in ocean circulation and increased marine primary production are, in fact, interdependent parameters. The problem is further complicated by other parameters such as the benthic release of reactive phosphorus available for primary producers which in turn seems to be related to oxygen content at the water sediment interface (Van Cappellen \& Ingall, 1994).

In the case of the Amadeus Segment, there is evidence of greater accumulation of organic matter during periods of lower fertility which results in a 'reversed' coupling between planktic and benthic foraminiferal assemblages. This can be explained only by a depletion of dissolved oxygen at the sea-floor as well as in the water column which enhanced both export rates and preservation of organic matter resulting in the deposition of the black shales. A possible decrease of downward flux of oxygen due to water stratification would have favoured the development of dysaerobic conditions allowing higher particulate fluxes to escape the surface water column during periods of lower primary productivity and lower seasonality. Contrarily, the lithotypes richer in organic matter would have deposited during periods of higher fertility. The possibility that higher concentrations of organic carbon within the black shales are mainly associated with changes in the sedimentation rate has to be excluded. The TOC records highs in the black shales even with $\mathrm{CaCO}_{3}$ free values (NTOC).

Understanding which mechanisms are responsible for the 
TROPHIC RESOURCE CONTINUUM

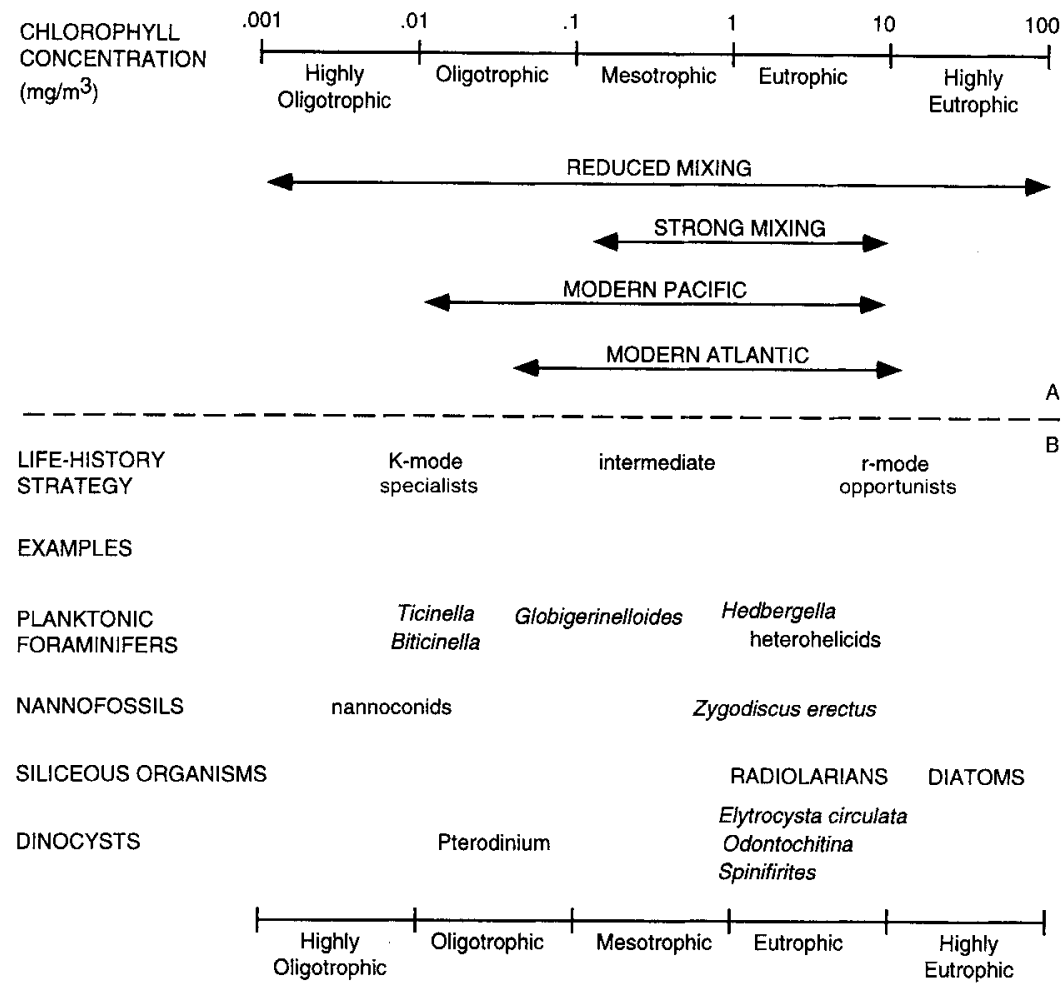

Fig. 8. Comparison of modern oceanic conditions (A) and those inferred for the Lower Cretaceous (B). After Hallock (1987) and Coccioni et al. (1993).

coupling between planktic and benthic foraminiferal assemblages is a crucial point to improve our knowledge of the palaeoceanographic conditions leading to organic carbon-rich facies.

\section{CONCLUSIONS}

Abundance, taxonomic composition, and diversity of planktic and benthic foraminiferal assemblages fluctuate markedly throughout the Amadeus Segment as a consequence of the change in fertility of surface waters and palaeoceanographic regime.

A relationship between lithology, NTOC, and planktic foraminiferal distribution patterns is recognizable, and variations in the relative abundance of different taxa are strongly related to changes in the nutrient supply and upper water column structure. In particular, Hedbergella indicates a more eutrophic habitat, whereas Ticinella and Biticinella preferred more oligotrophic conditions. Globigerinelloides would be an indicator of mesotrophic conditions. However, different species of Hedbergella emerge as poor palaeoecologic indicators as their record does not parallel the record of the genus to which they belong. Nutrient availability was the main limiting factor for Hedbergella, whereas Ticinella and Biticinella seem to be more sensitive to variations in temperature.

The response of benthic foraminifera to these fluctuations in the surface environment indicates a close coupling between the surface and bottom ecosystems, as the alternation of low and high primary productivity regimes resulted in rapid changes in the trophic structures of benthic foraminiferal assemblages which, according to Coccioni \& Galeotti (1993), are orbitally controlled. The preservation of a larger amount of organic matter during the deposition of black shales was apparently caused by oxygen depletion which allowed higher organic fluxes to the sea-floor rather than by higher primary productivity and/ or changes of sedimentation rate.

\section{ACKNOWLEDGEMENTS}

R. Coccioni, M. A. Kaminski, E. Erba and I. Premoli Silva are gratefully acknowledged for reading earlier drafts of the manuscript. The final version of this paper benefitted from comments and suggestions by M. B. Hart and J. W. Murray. This work has been supported by MURST $60 \%$ to R. Coccioni.

\section{Manuscript received September 1996 Manuscript accepted April 1997}

APPENDIX: Species list arranged in taxonomic order following Loeblich \& Tappan (1987)

\section{Planktic foraminifera}

Hedbergella delrioensis (Carsey, 1926)

Hedbergella planispira (Tappan, 1940) 
Calcareous Marl

\section{Surface waters:}

(i) More eutrophic conditions;

(ii) Higher productivity;

(iii) Good mixing of waters

(iv) Highest abundance of Hedbergella

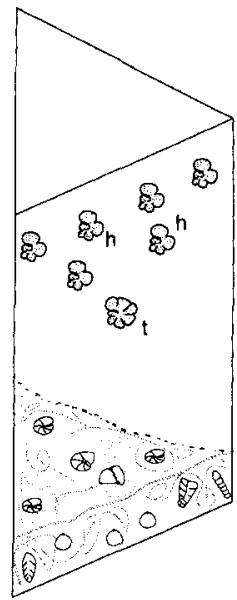

Benthic foraminiferal assemblages

(i) Low abundance;

(ii) Variable diversity;

(iii) Small-sized specimens $(<250 \mu \mathrm{m})$;

(iv) High dominance
Marl

\section{Surface waters:}

(i) Highest abundance of planktic foraminfera:

(ii) Hedbergella predominates

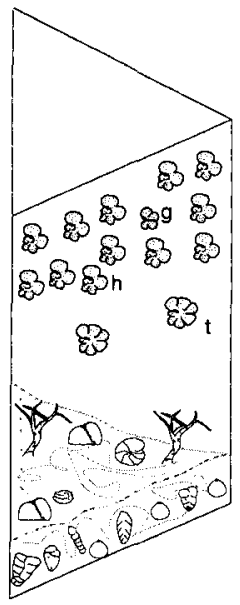

Benthic foraminiferal assemblages

(i) High abundance;

(ii) High diversity;

(iii) Large-sized specimens (>250 $\mu \mathrm{m}$ );

(iv) Predominance of low surface to volume ratio morphotype;

v) Low dominance

\section{Black-Shale}

\section{Surface waters:}

(i) More oligotrophic conditions;

(ii) Low productivity regime;

(iii) Ticinella and Biticinella become more abundant
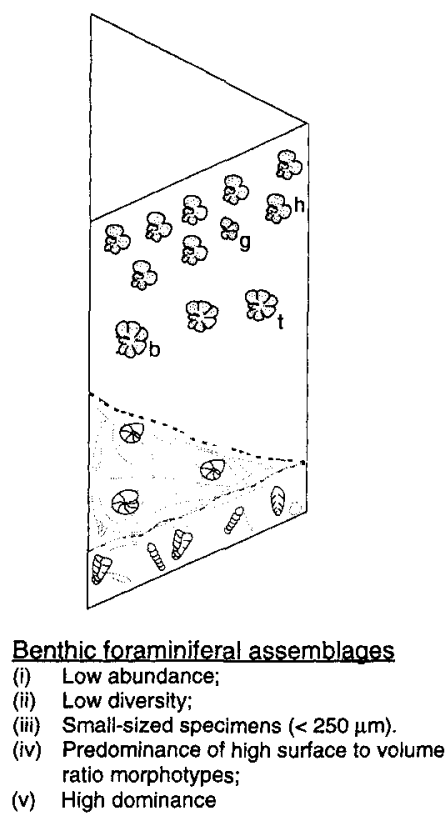

assemblages

Small-sized specimens $(<250 \mu \mathrm{m})$

ratio morphotypes;

(v) High dominance

Fig. 9. Amadeus Segment - Idealized palaeonvironmental reconstruction of the sea-floor related to different lithology and surface waters conditions. As regards planktic foraminifera Hedbergella and Globigerinelloides (labelled as $\mathrm{h}$ and g respectively) are placed in the uppermost water column whereas Ticinella and Biticinella (labelled as $\mathrm{t}$ and $\mathrm{b}$, respectively) are placed in deeper positions. As concerns benthic foraminifera, the inferred lifeposition within or onto the sea floor is according to the morphogroup organisation described in the text (see also Coccioni \& Galeotti, 1993).

Hedbergella rischi Moullade, 1974

Hedbergella simplex (Morrow, 1934)

Biticinella breggiensis (Gandolfi, 1942)

Ticinella albiana Longoria \& Gamper, 1977

Ticinella aperta Sigal, 1966

Ticinella caronae Longoria \& Gamper, 1977

Ticinella madecassiana Sigal, 1966

Ticinella petalloidea Longoria \& Gamper, 1977

Ticinella praeticinaensis Sigal, 1966

Ticinella primula Luterbacher \& Premoli Silva, 1962

Ticinella ex gr. raynaudi Sigal, 1966

Ticinella roberti (Gandolf, 1942)

Globigerinelloides caseyi (Bolli, Loeblich \& Tappan, 1957)

\section{Benthic foraminifera}

Rhabdammina ex gr. discreta Brady, 1881

Ammodiscus cretaceus (Reuss, 1862)

Eggerellina mariae Ten Dam, 1950

Arenobulimina ovoidea Marie, 1941

Dorothia glabrella Cushman, 1933

Dorothia gradata Berthelin, 1880

Dorothia pupa (Reuss, 1860)

Marssonella oxycona Reuss, 1860

Clavulinoides gaultinus (Morozova, 1948)
Tristix excavata (Reuss, 1863)

Astacolus polandensis Trujillo, 1960

Planularia complanata (Reuss, 1845)

Gyroidinoides nitidus (Reuss, 1846)

\section{REFERENCES}

Baccelle, L. \& Bosellini, A. 1965. Diagrammi per la stima visiva della composizione percentuale nelle rocce sedimentarie. Annali dell'Universitê di Ferrara, Ser. IX, 1(3): 59-62.

Bernhard, J. M. 1986. Characteristic assemblages and morphologies of benthic foraminifera from anoxic, organic-rich deposits: Jurassic through Holocene. Journal of Foraminiferal Research, 16: 207-215.

Bréhéret, J. G., Caron, M. \& Delamette, M. 1985. Les couches riches en matière organique et leurs conditions de dépôt. Documents du Bureau des Recherches Géologiques et Minières, 110: 141-191.

Caron, M. \& Homewood, P. 1983. Evolution of early planktic foraminifers. Marine Micropaleontology, 7: 453-462.

Coccioni, R. \& Galeotti, S. 1993. Orbitally induced cycles in benthonic foraminiferal morphogroups and trophic structures distribution patterns from the Late Albian 'Amadeus Segment' (Central Italy). Journal of Micropaleontology, 12: 227-239.

Coccioni, R., Erba, E. \& Premoli Silva, I. 1992. Barremian-Aptian calcareous plankton biostratigraphy from the Gorgo Cerbara section (Marche, central Italy) and implications for planktonic evolution. Cretaceous Research, 13: 517-537.

Coccioni, R., Galeotti, S. \& Santarelli, A. 1993. Preliminary palynological analysis of the Maiolica-Scisti a Fucoidi transition (BarremianAptian) in the Gorgo a Cerbara section (central Italy). Palaeopelagos, 3: 199-205. 
Coccioni, R., De Poli, A., Erba, E., Lottaroli, F. \& Premoli Silva, I 1990a. Lithostratigraphy and biostratigraphy of the Aptian-Albian Scisti a Fucoidi Formation (central Italy): evidence for hiatuses and their paleotectonic and paleoenviromental implications. $3^{\circ}$ Convegno Internazionale 'Fossili, Evoluzione. Ambiente', Pergola, 21-28 October 1990, 41 (abstract).

Coccioni, R., Franchi, R., Nesci, O., Perilli, N., Wezel, F. C. \& Battistini, F. 1990b. Stratigrafia, micropaleontologia e mineralogia delle Marne a Fucoidi delle sezioni di Poggio le Guaine e del Fiume Bosso (Appennino umbro-marchigiano). $2^{\circ}$ Convegno Internazionale 'Fossili, Evoluzione, Ambiente', Pergola, 25-30 October 1987. Tecnostampa, 163-201.

Coccioni, R., Franchi, R., Nesci, O., Wezel, F. C., Battistini, F. \& Pallecchi, P. 1989. Stratigraphy and mineralogy of the Selli Level (Early Aptian) at the base of the Marne a Fucoidi in the UmbroMarchean Apennines, Italy. In Wiedmann, J. (Ed.), Cretaceous of the Western Tethys. Proceedings 3rd International Cretaceous Symposium, Tubingen 1987, 563-584. E. Schweizerbart Verlagsbuchhandlung, Stuttgart

Coccioni, R., Nesci, O., Tramontana, M., Wezel, F. C. \& Moretti, E. 1987. Descrizione di un livello-guida 'radiolaritico-bituminoso-ittiolitico' alla base delle Marne a Fucoidi nell'Appennino umbromarchigiano. Bollettino della Società Geologica Italiana, 106(1): 183192.

Corliss, B. H. \& Chen, C. 1988. Morphotype patterns of Norwegian Sea deep-sea benthic foraminifera and ecological implications. Geology, 16: $716-719$.

de Boer, P. L. 1982. Cyclicity and storage of organic matter in Middle Cretaceous pelagic sediments. In Einsele, G. and Seilacher, A. (Eds.), Cyclic Event Stratification, 456-474. Springer Verlag, New York.

de Boer, P. L. \& Wonders A. A. H. 1984. Astronomically induced rhythmic bedding in Cretaceous pelagic sediment near Moria (Italy). In Berger, A. L., Imbrie, J., Hays, J., Kukla, G. \& Saltzman, B. (Eds.), Milankovitch and Climate, 177-190. D. Reiodel, Dordrecht.

Erba, E. 1992. Calcareous nannofossil distribution in pelagic rhythmic sediments (Aptian-Albian Piobbico core, Central Italy). Rivista Italiana di Paelontologia e Stratigrafia, 97, 455-484.

Erba, E. \& Premoli Silva, I. 1994. Orbitally driven cycles in trace-fossil distribution from the Piobbico core (late Albian, central Italy). Special Publication of the International Association of Sedimentimentologists, 19: $211-225$.

Fischer, A. G., Herbert, T. D. \& Premoli Silva, I. 1985. Carbonate bedding cycles in Cretaceous pelagic and hemipelagic sequences. In Pratt, L. M. et al. (Eds.), Fine Grained Deposits and Biofacies of Cretaceous Western Interior Seaway: Evidence of Cyclic Sedimentary Processes. Soc. Econ. Paleont. Min. Field Trip Guidebook, 4: 1-10.

Fischer, A. G. \& Herbert, T. D. 1986. Stratification rhythms: ItaloAmerican studies in the Umbrian Facies. Memorie della Società Geologica Italiana, 31: 45-51.

Fischer, A. G., Herbert, T. D., Napoleone, G., Premoli Silva, I. \& Ripepe, M. 1991. Albian pelagic rhythms (Piobbico core). Journal of Sedimentary Petrology, 61: 1164-1172.
Hart, M. B. \& Bailey, H. W. 1979. The distribution of Planktonic Foraminiferida in the Mid-Cretaceous of NW Europe. Aspekte der Kreide Europas. IUGS Series A, No. 6, 527-542.

Hallock, P. A. 1987. Fluctuations in the trophic resource continuum: A factor in global diversity cycles? Paleoceanography, 2: 457-471.

Herbert, T. D. \& Fischer A. G. 1986. Milankovitch climatic origin of mid-Cretaceous black shales rhythms in Central Italy. Nature, 321: 739-743.

Jones, R. W. \& Charnock, M. A. 1985. Morphogroups of agglutinating foraminifera. Their life position and feeding habits and potential applicability in (paleo)ecological study. Revue de Paléobiologie, 4: $311-320$

Koutsoukos, E. A. M. \& Hart, M. B. 1990. Cretaceous foraminiferal morphogroup distribution patterns, palaeocommunities and trophic structures: a case study from the Sergipe Basin, Brazil. Transaction of the Royal Society of Edinburgh: Earth Sciences, 81: 221-246.

Leary, P. N., Cottle, R. A., \& Ditchfield, P. 1989. Milankovitch control of foraminiferal assemblages from the Cenomanian of southern England. Terra Nova, 1: 416-419.

Leckie, R. M., 1987. Paleoecology of mid-Cretaceous planktic foraminifera: a comparison of open ocean and epicontinental assemblages. Micropaleontology, 33: 164-177

Loeblich, A. R. Jr. \& Tappan, J. H. 1987. Foraminiferal Genera and their classification. Van Nostrand Reinhold Company, New York, Vols 1 and 2, 1-970 and 1-212.

Premoli Silva, I. \& Erba, E. 1991. Orbitally driven cycles in trace fossil distribution from the Piobbico core, Late Albian, central Italy. Terra abstracts, 3(1): 289.

Premoli Silva, I. \& Sliter, W. V. 1994. Cretaceous planktonic foraminiferal biostratigraphy and evolutionary trends from the Bottaccione Section, Gubbio, Italy. Palaeontographia Italica, 82 (1995): 1-89.

Premoli Silva, I., Erba, E. \& Tornaghi, M. E. 1989 a. Paleoenvironmental signals and changes in surface fertility in mid-Cretaceous Corg-rich pelagic facies on the Fucoid Marls (central Italy). Geobios, mem. spéc., 11: $225-236$.

Premoli Silva, I., Ripepe, M. \& Tornaghi, M. E. 1989h. Planktic foraminiferal distribution record productivity cycles: evidence from the Aptian-Albian Piobbico core (central Italy). Terra nova, 1: 443448.

Schwarzacher, W. \& Fischer, A. G. 1982. Limestone-shale bedding and perturbations in the Earth's orbit. In Einsele, G. and Seilacher, A. (Eds.), Cyclic and Event Stratification, 72-95. Springer-Verlag.

Van Cappellen, P. \& Ingall, E. D. 1994. Benthic phosphorus regeneration, net primary production, and ocean anoxia: a model of the coupled marine biogeochemical cycles of carbon and phosphorus. Paleoceanography, 9: 677-692.

Wonders, A. A. H 1980. Middle and Late Cretaccous planktonic foraminifera of the western Mediterranean area. Utrecht Micropaleontological Bullettin, 24: 157. 